\title{
Determination of energy losses on switchgears of pneumatic transport of meat products
}

\author{
Sergei Beseda, Igor Litovchenko
}

\author{
National University of Food Technologies, Kyiv, Ukraine
}

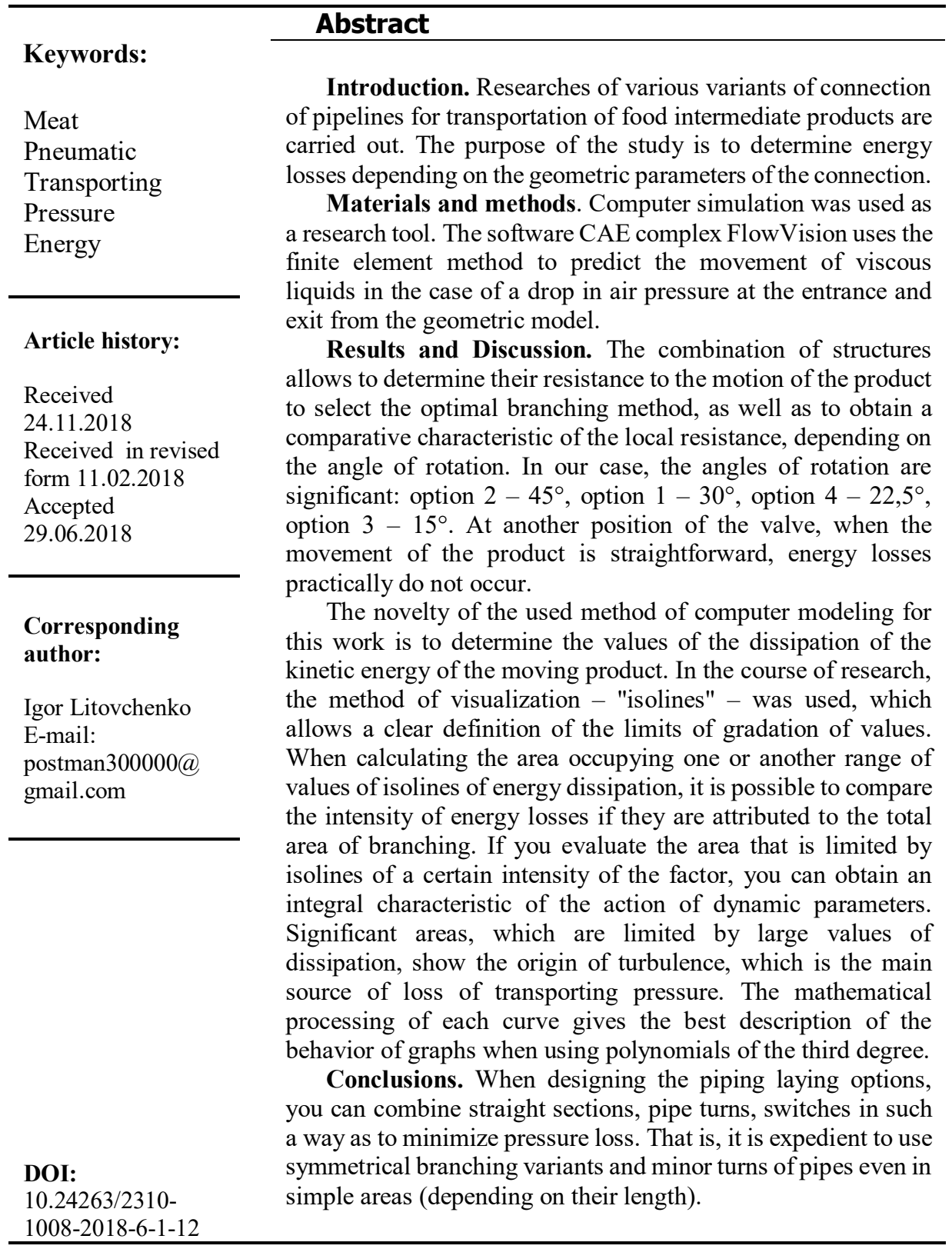




\section{Introduction}

The means of pneumatic transportation of raw materials, intermediate products and waste products at meat processing plants are a complex three-dimensional branched system. It includes sets of refueling tanks, pipelines of different diameters and lengths, branching with switches $[2,7]$.

In the case of the design [7] of a general system of pneumatic transport within the workshop or the whole enterprise, there are a number of options for constructive solutions for laying pipelines and connecting them to the general communications system $[1,5]$. By combining different variants of pipelines, branches (dampers) it is possible to determine the optimal variants of their gaskets for different production situations $[8,9,11]$. The criterion of optimality (target function) is the lowest energy consumption (compressed air) to provide the desired performance of the transport system $[18,19]$.

The purpose of this scientific study is to determine the effect of the design of various variants of branching pipelines that occur in production, on energy losses when passing through them a moving product.

\section{Materials and methods}

Materials. Table 1 shows variants of branches, which differ in structure - symmetric or asymmetric branching. For each of the options, different angles under which the pipes are directed are studied.

Table 1

\begin{tabular}{|c|c|c|}
\hline $\begin{array}{c}\text { Turn } \\
\text { angle, } \\
\text { degrees }\end{array}$ & Asymmetrical pipe separation & Symmetrical pipe separation \\
\hline & Option 1 & Option 2 \\
\hline & & \\
\hline
\end{tabular}




\section{- Processes and Equipment}

Table 2 shows in the section the structure of each branch in a situation where the damper changes the direction of movement of the product.

Table 2

\begin{tabular}{|l|l|l|}
\hline Turn angle \\
30 degrees
\end{tabular}

The combination of structures allows to determine their resistance to the motion of the product to select the optimal branching method, as well as to obtain a comparative characteristic of the local resistance, depending on the angle of rotation.

In our case, the angles of rotation are significant: option $2-45^{\circ}$, option $1-30^{\circ}$, option $4-22,5^{\circ}$, option $3-15^{\circ}$.

At another position of the valve, when the movement of the product is straightforward, energy losses practically do not occur.

The geometric and rheological conditions of the study are as follows:

- the diameter of the cylindrical part - $150 \mathrm{~mm}$;

- section of rectangular part - 150x150 mm;

- Product Density - $1050 \mathrm{~kg} / \mathrm{m}^{3}$;

- Product Viscosity - 0,01 Pa;

- air pressure in the pipeline system $-4 \times 10^{5} \mathrm{~Pa} /$

\section{Methods}

Computer simulation was used as a research tool.

The software CAE complex FlowVision uses the finite element method to predict the movement of viscous liquids in the case of a drop in air pressure at the entrance and exit from the geometric model. The boundary conditions of the "wall" with a given roughness determine slip and local pressure losses.

The basic ones in FlowVision are: the Navier-Stokes equation, the flow indeterminacy equation, and the equation for turbulent viscosity. In addition, the model includes equations for turbulent energy $\mathrm{k}$ and dissipation rates of turbulent energy $\varepsilon$. During the simulation a k$\varepsilon$ model of the turbulent flow of viscous fluid with small changes in density was used with large changes in the Reynolds number. The use of this program allows you to get unique scientific information in various fields of the food industry $[6,10]$. 


\section{- Processes and Equipment -}

The novelty of the used method of computer modeling for this work is to determine the values of the dissipation of the kinetic energy of the moving product. In the course of research, the method of visualization - "isolines" - was used, which allows a clear definition of the limits of gradation of values. When calculating the area occupying one or another range of values of isolines of energy dissipation, it is possible to compare the intensity of energy losses if they are attributed to the total area of branching.

If you evaluate the area that is limited by isolines of a certain intensity of the factor, you can obtain an integral characteristic of the action of dynamic parameters.

Significant areas, which are limited by large values of dissipation, show the origin of turbulence, which is the main source of loss of transporting pressure.

\section{Results and discussion}

Figures 1-4 show the simulation results of energy losses. The sequence of the layout of the figures is shown in the direction of decreasing the turning angle of the flow.

In order to generalize the results of the study, let's compare the results of measurements in the drawings of areas of dissipation of the same intensity (Figures 5).

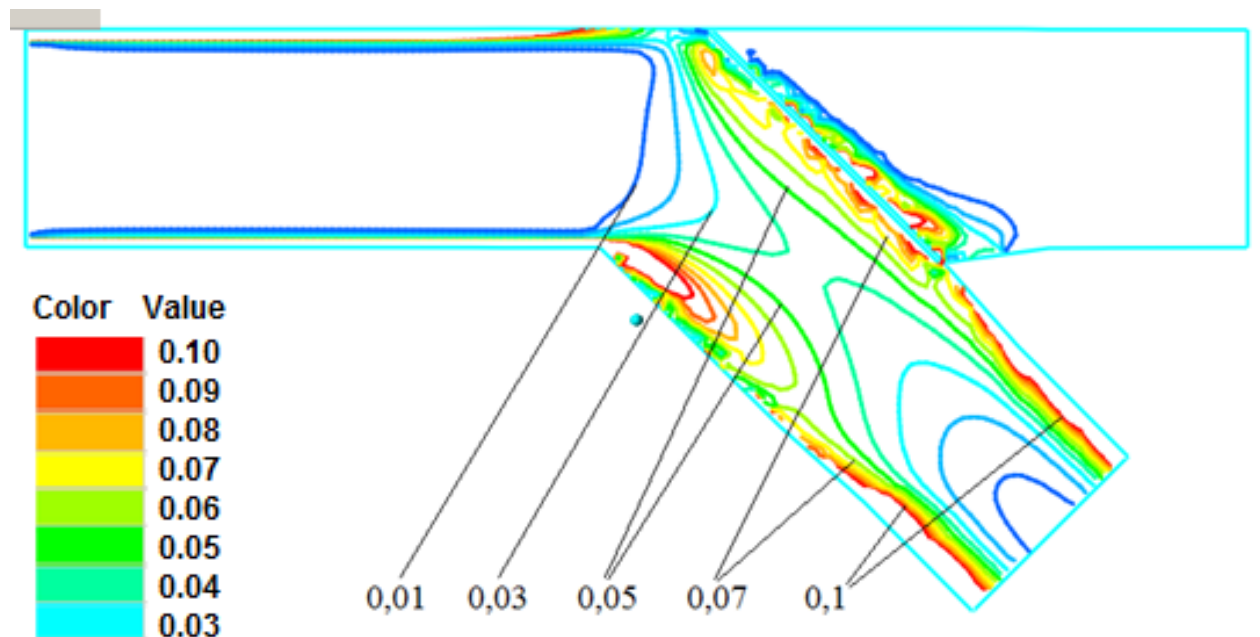

0.02

0.01

Figures 1. Isolations of dissipation of kinetic energy for asymmetrical branching with an angle of $45^{\circ}$ :

the corresponding area of values $-D=0,1 \mathrm{~m}^{2} / \mathrm{c}^{3}-10 \%$;

$D=0.05 \mathrm{~m}^{2} / \mathrm{s}^{3}-47 \% ; D=0.03 \mathrm{~m}^{2} / \mathrm{s}^{3}-18 \%$. 


\section{- Processes and Equipment -}

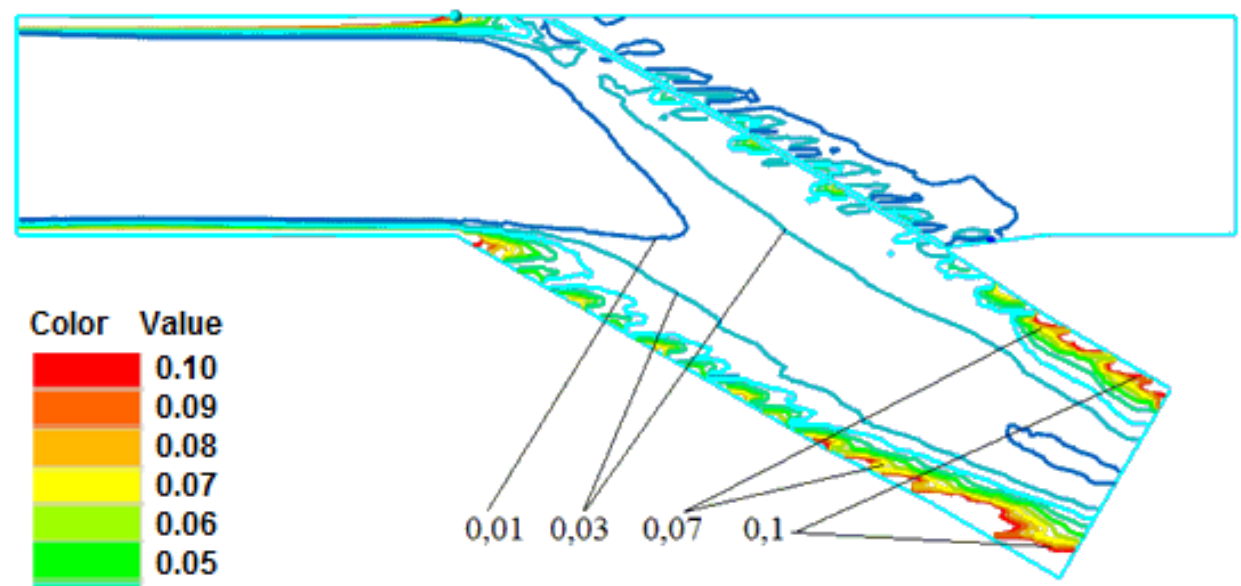

0.04

0.03

Figures 2. Isolations of dissipation of kinetic energy $D$ for asymmetric 0.02 branching with an angle of $30^{\circ}$ :

0.01

$$
\text { corresponding area of values }-D=0,1 \mathrm{~m}^{2} / \mathrm{c}^{3}-16 \% \text {; }
$$

$D=0.05 \mathrm{~m}^{2} / \mathrm{s}^{3}-84 \% ; D=0.03 \mathrm{~m}^{2} / \mathrm{s}^{3}-70 \%$.

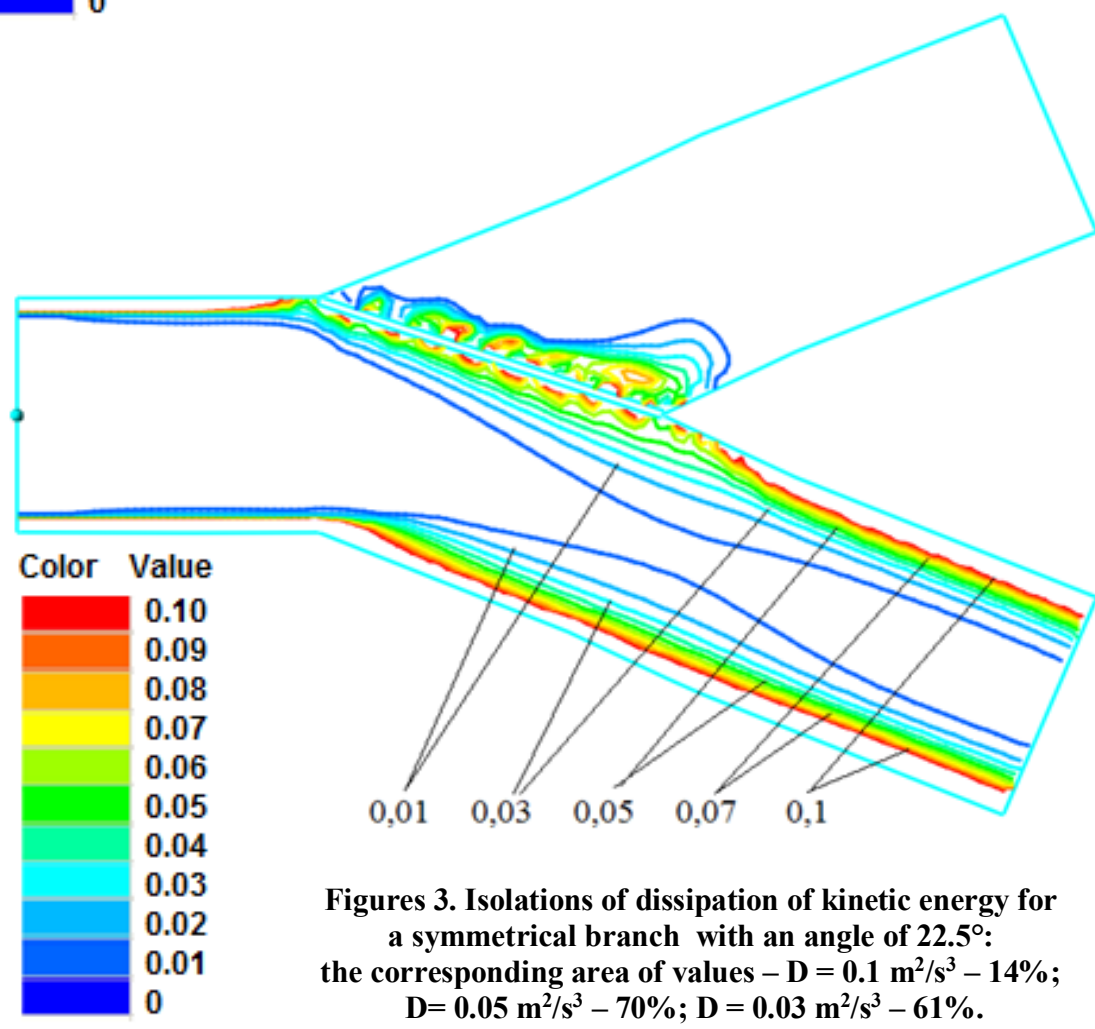



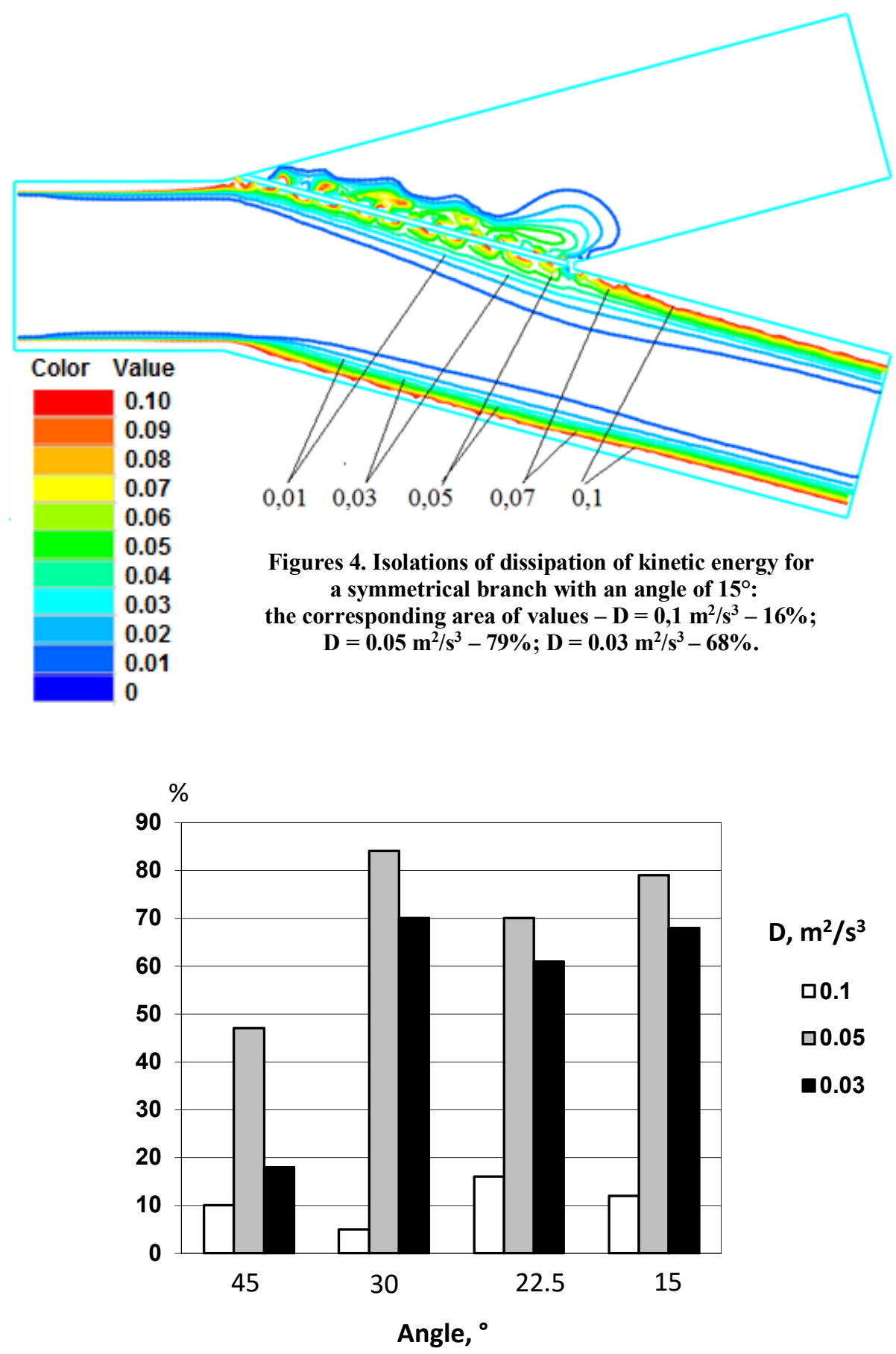

Figures 5. Percentage of the areas of areas of dissipation $D$ of a certain intensity as a percentage of the total area of the branching, depending on the angles of the flow of the stream 


\section{- Processes and Equipment -}

The mathematical processing of each curve gives the best description of the behavior of graphs when using polynomials of the third degree. Accordingly, the following equations represent the intensity of the course of dissipative processes depending on the type of branching and the numerical value of the angle of rotation.

\begin{tabular}{|c|c|}
\hline Dissipation, $\mathrm{m}^{2} / \mathrm{s}^{3}$ & Equation \\
\hline 0,1 & $\mathrm{y}=12 \mathrm{x}^{3}-99 \mathrm{x}^{2}+249 \mathrm{x}-115$ \\
\hline 0,05 & $\mathrm{y}=13 \mathrm{x}^{3}-108 \mathrm{x}^{2}+285 \mathrm{x}-172$ \\
\hline 0,03 & $\mathrm{y}=2 \mathrm{x}^{3}-16 \mathrm{x}^{2}+40 \mathrm{x}-16$ \\
\hline
\end{tabular}

Distortion occurs on the plate of the switch - the minimum gap between the wall and the plate is in reality and in the model about $1 \mathrm{~mm}$. It is important to note that a certain breakthrough in flow at these speeds and pressures is still happening.

Analyzing the obtained results, it can be noted that the dependence of energy losses on the geometry of the pipeline connection is rather complicated and is described by nonlinear dependencies.

This can be explained by the fact that changing the modeling parameters changes the criterial nature of the product motion $[17,23]$.

\section{Conclusions}

The length of rectilinear pipelines affects the cost of transportation energy much less than the local supports: turns of pipes and switches.

When designing the piping laying options, you can combine straight sections, pipe turns, switches in such a way as to minimize pressure loss. That is, it is expedient to use symmetrical branching variants and minor turns of pipes even in simple areas (depending on their length).

\section{References}

1. Beseda S.D., Shtefan Ye.V., Taran V.M. (2006), Vyznachennia ratsionalnykh konstruktyvnykh ta ekspluatatsiinykh kharakterystyk obladnannia dlia transportuvannia nekharchovoi miasnoi syrovyny, Miasnoe delo, 11, pp. 66-68.

2. Purnell G. (203), Robotics and automation in meat processing, Robotics and Automation in the Food Industry, Grimsby Institute of Further \& Higher Education (Gifhe), pp. 304-328.

3. Longdell G.R. (1994), Advanced technologies in the meat industry, Meat Science, 36(1-2), pp. 277-291.

4. Toledo R.T. (2007), Fundamentals of Food Process Engineering. Third Edition, Springer.

5. Beseda S.D., Lytovchenko I.M. (2014), Doslidzhennia parametriv rukhu miasnoi syrovyny v kruhlykh truboprovodakh pry pnevmotransportuvanni, Novi idei v kharchovii nautsi-novi produkty kharchovii promyslovosti: mizhnarodna naukova konferentsiia, prysviachena 130richchiu Natsionalnoho universytetu kharchovykh tekhnolohii, Kyiv, pp. 412. 


\section{- Processes and Equipment}

6. Shpak M.S., Litovchenko I.N. (2011), Modelirovanie osnovnykh protsessov v oborudovanii pishchevoi promyshlennosti, Inzhenernye sistemy: tezisy dokladov, mezhdunarodnaia nauchno-prakticheskaia konferentsiia, p. 4.

7. Lelieveld H., Holah J., Gabrić D. (2016), Handbook of Hygiene Control in the Food Industry (Second Edition), Elsevier.

8. Luchian M.I., Litovchenko I., Stefanov S., Csatlos C. (2012), Numerical simulation of energy dissipation in mixing process of bread dough, Journal of EcoAgriTourism, 25, pp. $67-70$.

9. Stefanov S., Hadjiiski W., Litovchenko I. (2012) Use of computer modeling for modernization of final proofers of preparation of dough, 12th International Conference "Research an d Development in Mechanical Industry" RaDMI 2012, 13-17 September 2012, Vrnjacka Banja, Serbia, P. 791-796.

10. Litovchenko I., Stefanov S., Hadzhiyski V. (2015), Investigation work proofers by computer simulation, Ukrainian Food Journal, 4(2), pp. 119-126.

11. Beseda S.D., Lytovchenko I.M. (2012), Modeliuvannia parametriv rukhu miasnoi syrovyny $\mathrm{v}$ systemakh pnevmatychnoho transportu, Naukovi pratsi Natsionalnoho universytetu kharchovykh tekhnolohii, 47, pp. 50-54.

12. Steven M. Lonergan, David G. Topel, Dennis N. Marple (2019), Chapter 15: Packaging for meat and meat products, The Science of Animal Growth and Meat Technology (Second Edition), pp. 255-269

13. James S.J., James C. (2014), MEAT MARKETING. Transport of Meat and Meat Products, Encyclopedia of Meat Sciences (Second Edition), 2014, pp. 236-243

14. Telychkun V.I., Gavva O.M., Telychkun Yu.S., Gubenia O.O., Desyk M.H., Chepeliuk O.M. (2017), Tekhnolohichni kompleksy kharchovykh vyrobnytstv, Stal, Kyiv.

15. Brennan J. G., Alistair S.G. (2011), Food Processing Handbook, 2nd Edition, Wiley-VCH Verlag GmbH \& Co.

16. Litovchenko I., Taran V., Beseda S., Hadjiiski W. M., Stefanov S.V. (2011), Computer modelling of movement of meat raw material on pipelines, The 7th International Conference «Integrated systems for agri-food production», Nyiregyhaza, Hungary, pp. 211-214.

17. Fellows P. (2013), Food processing technology. Principles and Practice. Second Edition, CRC Press.

18. Holah J., Lelieveld H.L.M. (2011), Hygienic Design of Food Factories, Elsevier

19. Kennedy S. (2017), Food Protection and Security. Preventing and Mitigating Contamination during Food Processing and Production, Woodhead Publishing.

20. Litovchenko I. (2013), The study of the baking ovens by computer simulation, Food technology, XVII, pp. 107-115.

21. Ralko O. (2012), The restructuring and organisational development in the food industry in Ukraine, in: Tetyana Mostenska, Iryna Fedulova, Virginija Jurėnienè (2012), Restructuring: theory and practice: [monograph], Kyiv: Kondor, pp. 171-195.

22. Beseda S. D., Lytovchenko I.M. (2016), Enerehetychni pokaznyky protsesu pereduvky miasnoi syrovyny, Naukovi pratsi Natsionalnoho universytetu kharchovykh tekhnolohii, pp. $120-125$.

23. Yiu H. Hui. (2006), Handbook of Food Science, Technology, and Engineering, CRC Press. 